\title{
The Relationships Between Music Performance Anxiety and the Mindfulness Levels of Music Teacher Candidates
}

\author{
Birsen Jelen ${ }^{1}$ \\ ${ }^{1}$ Music Education Department, Gazi Facyulty of Education, Gazi University, Ankara, Turkey \\ Correspondence: Birsen Jelen, Music Education Department, Gazi Faculty of Education, Gazi University, Ankara, \\ Turkey.
}

Received: May 5, 2021

Accepted: July 7, $2021 \quad$ Online Published: September 26, 2021

doi:10.5539/ies.v14n10p116

URL: https://doi.org/10.5539/ies.v14n10p116

\begin{abstract}
In this study the relationships between the Music Performance Anxiety (MPA) levels and mindfulness levels of Music Teacher Candidates (MTC) were investigated. A large sample of undergraduate students $(\mathrm{N}=524)$ from seven different universities from around Turkey took place in the study. The data was collected with both Kenny's MPA inventory and the Five Facets Mindfulness Questionnaire. The Pearson Moments Correlation Coefficient was used in determining the relationships between the MPA and mindfulness levels of the MTC. To determine whether the MPA of students and mindfulness differ in terms of piano lesson achievement and daily piano practice time (DPPT) variables, a variance analysis (ANOVA) and a Kruskal Wallis H test analyses were used. Students' mindfulness levels were negatively correlated with their MPA levels. Their piano lesson achievement levels had positive relationship with mindfulness and a negative relationship with their MPA. Similarly, their DPPT had a positive relationship with mindfulness and a negative relationship with MPA.
\end{abstract}

Keywords: music performance anxiety, mindfulness, music teacher candidates, piano, practice time, achievement

\section{Introduction}

Mindfulness is focusing one's attention at the present moment which takes its foundation from the tradition of Eastern meditation. It is defined as the intentional awareness of the internal and external happenings in the present moment, without judgment, rejection, or attachment to the moment (Kabat-Zinn, 2012) bringing the mind into the present moment when it wanders around without an aim (Bishop et al. 2004). This kind of focus 'nurtures greater awareness, clarity and acceptance of the present-moment's reality' (Kabat-Zinn, 1994). Although, descriptions of mindfulness can vary, they all include the process of focusing one's attention on an 'object' (e.g., breath, body sensations, or image), being distracted from the object, noticing and acknowledging the distraction, and returning one's attention back to the object (Bishop et al., 2004; Kabat-Zinn, 1990; Steinfeld \& Brewer 2015; Ruiz, Dvorak, $\&$ Weingarten, 2020). Mindfulness is endangered when the individual acts with automated-conditional reactions or impulses, and at the same time does not pay attention to his/her behaviour; that is to say, 'mindfulness' is lost or damaged (Ozyesil, Arslan, Kesici, \& Deniz 2011). 'When one is being mindful, one does not get attached to thoughts or feelings-one makes note of them and then lets them go. If a distraction in concentration occurs, mindfulness means noticing the distraction and bringing one's focus back to the task at hand' (Oyan, 2006).

One of the two most important factors in the success of music performance is 'concentrating all attention to the actual performance' and the other is 'providing emotional management'. In this context, mindfulness is of great importance for the musician. The working processes of the musicians reinforce a certain understanding of interpretation for each passage of the work; this intellectual ground constantly reveals itself in the same form of repeated motional behaviour. After a while, the mind and muscles perform a total memorization of these movements. In this regard, the playback of a particular work in a certain way provides almost automated behaviour integrity. If 'anxiety' occurs during performance, these automatic behaviours will be damaged. For example, when a person starts to think about his or her performance during performance, automatic behaviours are broken or blocked (Tokinan, 2013). As Salmon and Meyer (1992) point out 'when the playing becomes automated one's attention is free to wander elsewhere, frequently to irrelevant thoughts. You are, in effect, consciously doing two things at once-performing and thinking-but not directing your full attention to either one. Since these two activities are parallel, yet not strictly related to each other, you may find yourself attending to first one, then the other, and feeling that you're not focused on the music. Instead, you are consciously aware of both thinking and playing, 
without being fully involved in either' which means not being mindful during practice. If one can learn to be mindful during musical practice similar to other ordinary activities, being mindful during musical performance will be a more natural response (Oyan, 2006). So, even when anxiety appears while playing, being mindful could help in coping with anxiety during a musical performance.

MPA is described as the deterioration of performance in front of the audience or being constantly worried about disrupting the music performance. MPA occurs independently from a performers talent, education level or preparation time (Valentine, 2002). Kafadar describes performance anxiety as, a kind of social anxiety disorder which is frequently seen in musicians. Excessive anxiety may cause disorientation, nervousness, memory errors, an uneasy mood, bodily tension, the fear of going on stage and self-talk (Kafadar, 2009). Research of musicians' self-talk content before a performance (Steptoe, \& Fidler 1987; Tokarz, \& Kaleńska 2005) indicated that MPA is associated with a catastrophic style of thinking, while positive thinking strategies may reduce MPA. Focusing on the playing of music and a development-oriented, self-accepting attitude promotes well-being on stage (Rodzaj, 2020). Consequently, it could be concluded that mindfulness may be related to MPA, due to its relation to being a wide-ranging branch of social anxiety (Cruz, \& Carvajal 2014). In the studies made by Davidson (1998) and Kabat-Zinn (2003), it was observed that people who participated in mindfulness practices established their emotional and physical balance stronger than those in the control group. Another study that supports these findings belongs to Brown and Ryan (2003) who found significant relationships between 'high mindfulness scores' and less anxiety, less depression, less negative emotion, high positive levels of emotionality, vitality, enjoyment of life, self-confidence, optimism and self-realization. Jha, Krompinger and Baime (2007), suggested that focusing one's attention to a particular task like orientation and maintaining attention could be beneficial for musical performance.

Mindfulness, on the one hand, is conceptualized as a situational experience experienced during mindfulness exercises. On the other hand, it is considered as a skill that can be developed, or even as a trait that is vested without being aware of it (Sahin \& Yeniceri 2015). In an article in which abundant research was collected, Keng, Smoski, and Robins (2011), argued that mindfulness is a variable that can be associated, as a personal trait, a skill or an intervention style which can be found in various samples of people; such as university students, adults of the general public, or patients treated in a clinic. When mindfulness is considered as a personality trait, it is claimed that those who have a high mindfulness level, have at the same time higher levels of psychological wellbeing including self-acceptance, positive relations with others, autonomy, environmental mastery, purpose in life, personal growth and tend to be more self-disciplined, reliable and hardworking (Bowlin, \& Baer, 2012). There is also evidence that mindfulness is related to executive functions and emotional management as a personality trait, based on the functional integrity of the prefrontal cortex (Sahin \& Yeniceri, 2015).

Like all instrumentalists, music teacher candidates also devote hours to piano and other musical instruments studies to improve their authority in the instrument. However, these efforts are not sufficient enough to prevent the encounter of cognitive and temporal errors or physiological problems caused by MPA while playing in front of an audience (Jelen, 2017). The purpose of this study is to investigate the relationships between MPA levels and mindfulness levels of MTC where mindfulness was examined as a examined as a personal trait. For the purpose of the study, the following questions were sought:

Is there a significant relationship between the levels of MPA and mindfulness levels of MTC?

Do the MPA levels differ in terms of piano lesson achievement variable of MTC?

Do the levels of mindfulness differ in terms of piano lesson achievement variable of MTC?

Do MPA levels differ in terms of DPPT variable of MTC?

Do the mindfulness levels differ in terms of the (DPPT) variable of MTC?

\section{Method}

\subsection{Research Model}

The model of this research which was conducted to determine the relationships between MPA and mindfulness levels of MTC is a relational screening research model. Relational screening models are research models aiming to determine the presence and/or degree of coexistence between two or more variables (Karasar, 2004).

\subsection{Participants}

A large sample of undergraduate students $(\mathrm{N}=524)$ from seven different universities around Turkey ( Gazi University, Muğla Sıtkı Koçman University, Harran University, Atatürk University, Çanakkale 18 Mart University, Karadeniz Teknik University and Mehmet Akif Ersoy University) took place in the study. The participants were 
chosen randomly, $186(36 \%)$ of which were male and $336(\% 64)$ female.

\subsection{Data Collection Tools}

The Personal Information Form, Kenny MPA Inventory and the Five Facets Mindfulness Questionnaire (FFMQ) were used as data collection tools.

1) Personal Information Form: In order to determine the demographic characteristics of MTC, Personal Information was prepared by the researcher. It included questions about students' gender, daily piano practice hours and piano lesson grades.

2) Kenny MPA Inventory: Kenny MPA Inventory Kenny, Davis and Oates (2004). The original form of the inventory consists of 40 items distributed over 12 sub-factors. These 12 factors were categorized under three headings. (i) early relationship status [transfer of anxiety from generation to generation; familial empathy] (ii) psychological vulnerability [depression/hopelessness; controllability; confidence; (iii) connected performance states [associated somatic concern; fear/horror (negative perception); considerations before and after performance; personal inspection/supervision by others; opportunity price; memory reliability. The study of language equivalence, validity and reliability studies and adaptation of the inventory to the Turkish culture was conducted by Tokinan (2013). As a result of the validity and reliability studies, it was determined that the Turkish version of the inventory consisted of 25 items that were scattered into five factors as negative performance perception, psychological vulnerability, somatic anxiety, personal control and physiological vulnerability. In addition, the Cronbach Alpha reliability coefficient of the scale was found to be .90 . The item total correlations ranged from .34 to .65 .

3) FFMQ: FFMQ was used to measure the general mindfulness trends in daily life (Baer, Smith, Hopkins, Krietemeyer, \& Toney 2006). The scale consists of five dimensions and five items. The Cronbach alpha value of the scale was $\alpha=.86$. The adaptation study was done by Kinay (2013). The Cronbach Alpha internal consistency coefficient of the scale ranged from .67 to .85 . As a result of the factor analysis performed to determine the factor structure of the FFMQ, it was concluded that the scale shows a five dimensional structure consisting of observing, defining, behaving with awareness, judging internal experiences, and responding to inner experiences. The common burden of the FFMQ for each substance varies between .38 and .79 . the test-retest correlation of the scale was found between .23 and .71 .

The Cronbach alpha value, which was calculated according to the data obtained from the Kenny MPA Inventory and the FFMQ used for data collection, is given in Table 1.

Table 1. Cronbach's Alpha Coefficients for data obtained from scales used in data collection

\begin{tabular}{lc}
\hline & Cronbach Alfa \\
\hline Kenny MPA Inventory & 0.940 \\
FFMQ & 0.644 \\
\hline
\end{tabular}

When the Table 1 is examined, Cronbach Alpha Coefficients of the Kenny MPA Inventory and the FFMQ show high reliability.

\subsection{Data Analysis}

The data of the study was analysed with the SPSS 21 package program. The Pearson Correlation Coefficient was used to determine the relationships between the MPA levels and mindfulness levels of MTC. The Pearson Correlation Coefficient ( $\mathrm{r}$ ) provides information on the strength and direction of the linear relationship between the two variables indicated by the measurement. The Pearson correlation coefficient ranges from -1 to +1 . The correlation coefficient decreases the force of the relationship when approaching 0 in both directions. The force of the relationship increases when approaching 1 in both directions (Alpar, 2016). The Pearson Correlation Coefficient, variance analysis (ANOVA) and Kruskal Wallis H Test analyses were used to determine whether the MPA and mindfulness levels of MTC differ in terms of achievement and DPPT variable. Before the analysis, the assumptions of normality and homogeneity were examined (see Table 2 and 3 ). In addition, before the analysis, the data were examined in terms of whether there is a lost value and the rate of lost value in the items changed between $0.2 \%$ and $0.8 \%$. By using the EM (Expectation Maximization) method, the most appropriate values were used instead of the missing values. 
Table 2. Analysis of normality and homogeneity assumptions of MPA and mindfulness levels according the achievement in piano lessons variable

\begin{tabular}{ccccc}
\hline & Skewness (sh) & Kurtosis (sh) & Kolmogorov-Smirnov (p) & Shapiro-Wilk (p) \\
\hline \multirow{2}{*}{ MPA } & -0.271 & -0.251 & $\begin{array}{c}0.071 \\
(0.000)\end{array}$ & $\begin{array}{c}0.987 \\
(0.000)\end{array}$ \\
\hline \multirow{2}{*}{ Mindfulness } & 0.656 & 0.630 & $\begin{array}{c}0.080 \\
(0.000)\end{array}$ & $\begin{array}{c}0.977 \\
(0.000)\end{array}$ \\
\hline \multirow{2}{*}{ Achievement in Piano Lessons } & -0.705 & \multirow{2}{*}{1.040} & $\begin{array}{c}0.099 \\
(0.000)\end{array}$ & $\begin{array}{c}0.960 \\
(0.000)\end{array}$ \\
\hline
\end{tabular}

Table 2 shows that normality assumptions are provided according to the variable of achievement, MPA and mindfulness levels.

Table 3. Analysis of normality and homogeneity assumptions of MPA and mindfulness levels according to the DPPT variable

\begin{tabular}{|c|c|c|c|c|c|c|}
\hline & & Skewness (sh) & Kurtosis (sh) & Kolmogorov-Smirnov (p) & Shapiro-Wilk (p) & Levene F Test (p) \\
\hline \multirow{3}{*}{ MPA } & Less than 1 hour & -0.249 & 0.061 & $\begin{array}{c}0.068 \\
(0.001)\end{array}$ & $\begin{array}{c}0.991 \\
(0.037)\end{array}$ & \multirow{3}{*}{$\begin{array}{c}5.612 \\
(0.004)\end{array}$} \\
\hline & $1-2$ hours & -0.221 & -0.734 & $\begin{array}{c}0.099 \\
(0.001)\end{array}$ & $\begin{array}{c}0.971 \\
(0.003)\end{array}$ & \\
\hline & More than 2 hours & -0.052 & -0.399 & $\begin{array}{c}0.071 \\
(0.200)\end{array}$ & $\begin{array}{c}0.982 \\
(0.802)\end{array}$ & \\
\hline \multirow{3}{*}{ Mindfulness } & Less than 1 hour & 0.606 & 0.656 & $\begin{array}{c}0.099 \\
(0.000)\end{array}$ & $\begin{array}{c}0.970 \\
(0.000)\end{array}$ & \multirow{3}{*}{$\begin{array}{c}0.339 \\
(0.713)\end{array}$} \\
\hline & $1-2$ hours & 0.416 & 0.579 & $\begin{array}{c}0.068 \\
(0.073)\end{array}$ & $\begin{array}{c}0.985 \\
(0.086)\end{array}$ & \\
\hline & More than 2 hours & 0.958 & 0.828 & $\begin{array}{c}0.112 \\
(0.200)\end{array}$ & $\begin{array}{c}0.928 \\
(0.022)\end{array}$ & \\
\hline
\end{tabular}

Table 3 shows that the normality and variance homogeneity assumptions for mindfulness levels of students are provided according to the DPPT variable, while MPA levels normality and variance homogeneity assumptions are not provided in terms of the DPPT variable.

\section{Findings}

The relationship between the MPA levels and mindfulness levels of MTC was investigated with the Pearson Correlation Coefficient and the results are given in Table 4.

Table 4. Relationship between MPA and mindfulness levels

\begin{tabular}{ccc}
\hline & & MPA Level \\
\hline \multirow{3}{*}{ Mindfulness Level } & $\mathrm{r}$ & -0.303 \\
\cline { 2 - 3 } & $\mathrm{p}$ & $0.000^{*}$ \\
\cline { 2 - 3 } & $\mathrm{N}$ & 524 \\
\hline
\end{tabular}

$* \mathrm{p}<0.05$.

When Table 4 is examined, there is a moderate negative correlation between MPA levels and mindfulness levels of MTC $(r=-0.303)$ which is statistically significant $(\mathrm{p}<0.05)$. The level of MPA decreases as the level of mindfulness increases. When the determination coefficient $\left(\mathrm{r}^{\wedge} 2=0.091\right)$ is observed, it is seen that the co-variability between the two variables is $9.1 \%$. In other words, mindfulness level explains $9.1 \%$ of the variability in MPA level.

The relationship between the musical performance anxiety levels of MTC and their achievement in piano lessons was examined with the Pearson moments product correlation coefficient and the results are given in Table 5. 
Table 5. The relationship between MPA and achievement in piano lessons

\begin{tabular}{cccc}
\cline { 2 - 3 } Achievement in Piano Lessons & \multicolumn{3}{c}{ MPA Level } \\
\cline { 2 - 3 } & \multicolumn{2}{c}{$\mathrm{R}$} & -0.081 \\
\cline { 2 - 3 } & $\mathrm{P}$ & $0.065^{*}$ \\
\hline & $\mathrm{N}$ & 524 \\
\hline
\end{tabular}

$* \mathrm{p}>0.05$.

Table 5 shows that there is a very low negative relationship between the MPA level and achievement in the piano lessons $(r=-0,081)$ and this relationship is not statistically significant $(p>0.05)$. According to the determination coefficient $\left(\mathrm{r}^{\wedge} 2=0.007\right)$, the co-variability between the two variables is $0.7 \%$.

The relationship between the level of mindfulness of MTC and their achievement in piano lessons was examined with the Pearson moments correlation coefficient and the results are given in Table 6.

Table 6. The relationship between the mindfulness levels and achievement in piano lessons

\begin{tabular}{lll}
\hline & \multicolumn{2}{c}{ Mindfulness Level } \\
\hline \multirow{3}{*}{ Achievement in Piano Lessons } & $\mathrm{r}$ & 0.149 \\
\cline { 2 - 3 } & $\mathrm{p}$ & $0.001 *$ \\
\cline { 2 - 3 } & $\mathrm{N}$ & 524 \\
\hline
\end{tabular}

$* \mathrm{p}<0.05$

Table 6 shows a low positive correlation between the level of mindfulness of MTC and their achievement levels in piano lessons $(\mathrm{r}=0.149)$ and this relationship is statistically significant $(\mathrm{p}<0.05)$. According to the determination coefficient $\left(\mathrm{r}^{\wedge} 2=0.022\right)$, the co-variability between the two variables is $2.2 \%$.

Since the assumptions for the performance anxiety level of the MTC are not provided, the Kruskal Wallis H test was used to determine whether the DPPT are different and the results are given in Table 7.

Table 7. Kruskal Wallis H test results of MPA levels according to DPPT variable

\begin{tabular}{|c|c|c|c|c|c|c|c|}
\hline & & $\mathrm{N}$ & Mean Rank & $\mathrm{Sd}$ & $\chi^{2}$ & $\mathrm{P}$ & Meaningful Difference \\
\hline \multirow{3}{*}{ Music Performance Anxieties } & Less than 1 hour & 331 & 273.24 & \multirow{3}{*}{2} & \multirow{3}{*}{6.703} & \multirow{3}{*}{$.035 *$} & \multirow{3}{*}{$1-3$} \\
\hline & 1-2 hours & 155 & 246.97 & & & & \\
\hline & More than 2 hours & 36 & 216.11 & & & & \\
\hline
\end{tabular}

$* \mathrm{p}<0.05$.

Table 7 shows that the MPA of MTC differ according to their DPPT $\left(\chi^{2}=6.703 ; \mathrm{p}<0.05\right)$. The Mann Whitney U test was conducted between the two sub-groups in order to find out between which piano practices duration are the differences in the levels of MPA.

Since the normal distribution and the homogeneity of variance were observed according to the DPPT for the mindfulness level, the single factor ANOVA was used and the results are summarized in Table 8.

Table 8. Results of single-factor ANOVA concerning MTC' mindfulness levels DPPT variable

\begin{tabular}{cccccccc}
\hline & & Sum of Squares & Sd & Squares Mean & F & P & Meaningful Difference \\
\hline \multirow{3}{*}{ Mindfulness } & Intergroup & 4123.566 & 2 & 2061.783 & & & \multirow{2}{*}{13.377} \\
\cline { 2 - 5 } & Within Groups & 79990.393 & 519 & 154.124 & $000 *$ & $1-2 /$ \\
\cline { 2 - 5 } & Total & 84113.959 & 521 & & & & $1-3 / 2-3$ \\
\hline
\end{tabular}

$* \mathrm{p}<0 . \overline{05}$

When Table 8 is examined, it shows that the level of mindfulness of MTC varies according to DPPT (F (2.519)= 13.377; $\mathrm{p}<0.05)$. The Tukey test was conducted to determine between which piano practice duration results in the 
difference in mindfulness levels. According to the results, the students who practice less than 1 hour $(\bar{X}=122.99)$ per day and those who practice piano 1-2 hours per day $(\bar{X}=126.67)$ have lower mindfulness levels than those who practice piano more than 2 hours a day $(\bar{X}=133.19)$.

\section{Discussion, Conclusion and Recommendations}

Attentiveness and focus are an indispensable part of music performance. Focusing one's attention to the performance (which is performed in the moment) and the effective control of emotions are important factors for successful performance. It is often observed that musicians tend to disrupt their positive performance behaviour during performance due to anxiety. The results of many studies suggest that, when the performers begin thinking about their performance while performing, generally their performance gets disrupted (Gabrielson, 1999; Lang, 2000; Yoshie, Kudo, \& Ohtsuki, 2008; Tokinan, 2013). Oyan (2006) in her research indicated that mindfulness has a positive effect on MPA. Research conducted previously shows a significant negative relationship between music performances' indispensable element 'attention', and MPA (Chang, Midlarsky, \& Lin, 2003; Lin, Chang, Zemon, \& Midlarsky, 2008). In light of the results of this study, a statistically significant medium negative correlation between the MPA levels and the mindfulness levels of the MTC was found. This shows that as the MTC' levels of mindfulness increase their level of MPA decreases. In this respect it can be suggested that students who have high mindfulness levels while performing musical instruments are less anxious. This result is consistent with the results of Brown and Ryan (2003) that associated high mindfulness scores with low anxiety levels. Saucier (2011) examined mindfulness as a personal trait and found a negative correlation between mindfulness and chronic stress. Similarly, Ulev (2014) indicated that the level of mindfulness predicts the level of depression, anxiety and stress; so as the level of mindfulness increases, depression, anxiety and stress levels lower. Bowlin and Baer (2012) also found out that mindfulness was negatively correlated with general distress. Grodd and Cameron (2013) found that being able to act with awareness during music performance is a strong predictor of a lower level of MPA. In addition, Cruz and Carvajal (2014) stated that in general it seems that mindfulness can be characterized by an important interaction with the art of music in many contexts, such as turning MPA into performance facilitating, apart from enhancing psychological well-being in musicians (Cruz \& Carvajal, 2014). The negative correlation between mindfulness and musical performance anxiety is also supported by the findings of many other previous studies (Chang et al., 2003; Lin et al., 2008; Grodd, 2012).

According to Kenny, Davis, and Oates (2004), musical performance is a complex process involving well-trained skills such as fine motor skills, coordination, memory, aesthetics and interpretation; a high level of MPA can damage the success of the performance of the performer. In the related literature, it is frequently mentioned that anxiety has a negative effect on academic achievement (Metallidou \& Vlachou, 2007; Wolters \& Pintrich, 1998; Yildirım, 2011). In the light of the results obtained in the present study, a very low level negative relationship was found between the achievement level in piano lessons and the MPA level of the MTC. In other words, the MTC's level of MPA decreases as their achievement scores in piano lessons increases. Studies that investigated the relationship between anxiety and achievement in the field of music education had similar results. The negative relationship between achievement and anxiety is supported by the findings of many other previous studies (Sarason \& Mandler, 1952; Morris, Kellaway, \& Smith 1978; Alyaprak, 2006; Duman, 2008). It was consistently found that there was a negative relationship between MTC's musical instrument achievement scores and test anxiety, (Kucuk, 2010; Nacakcı \& Dalkıran 2011), MTC's trait anxiety levels and academic achievement (Yokus, Yokus, \& Kalaycioglu 2013), MTC's piano achievement scores and MPA (Gun \& Y1ldız, 2014), and MTC's social avoidance and piano achievement scores (Pirgon, 2017). Unlike the studies that have been counted so far, Guven (2016) did not find a significant relationship between the MTC's piano achievement scores and their test anxiety, her results are in contradiction with the findings of other studies showing that anxiety has negative effects on students' academic performance.

Attention is the basis of mindfulness. To achieve academic achievement, attention is also very important. As with most skills, the maintenance of attention develops with its application. Students trained on mindfulness can better focus their attention on the task or their course and also filter out distractors (Rodgers, 2014; Leland, 2015). In the present study a positive correlation was found between the level of mindfulness of the MTC and their achievement scores in piano lessons. According to this result, as the level of mindfulness increases, the level of piano lesson achievement increases. This suggests that successful music performers are naturally mindful or a way to be successful as a music performer is to know how to be mindful. It can be also said that students who mindfully practice piano are becoming more successful. For students to become more successful in their music performances, practicing mindfulness could be helpful. In the study of Kocaarslan (2016) meaningful differences between MTC academic achievement and mindfulness was found, which is compatible with the result of the present study. Accordingly, students who have high academic achievement have higher mindfulness levels than 
other students (Kocaarslan, 2016). Studies, show that mindfulness practices help students to increase their postgraduate enrolment exam scores, it was useful in focusing on academic studies (Schwind et al., 2017) and mindfulness was associated positively with high academic achievement (Brown, \& Ryan, 2003; Brown, Ryan, \& Creswell 2007). Therefore, it can be said that mindfulness has a positive effect on students' achievement. Although research on mindfulness in the academic context is limited (Howell \& Buro, 2011; Shapiro, Brown, Thoresen, \& Plante, 2011), the findings of the existing studies on the subject differ (Hall, 1999; Weinstein, Brown \& Ryan 2009). In contrast to the results mentioned above Grodd and Cameron (2013) did not find a relationship between mindfulness and achievement. Brausch (2011) found that the hypothesis that mindfulness is a predictor of academic achievement could not be verified.

Another result obtained in the present study showed that the MPA of the MTC differed according to their DPPT. It was found out that students' MPA decreased as their DPPT increased. This result is not compatible with the study of Topoglu (2014), who found that there was no correlation between the state of anxiety levels of MTC and their daily musical instrument practice hours. Ryan (2004) observed that although it was important to practice in order to have a successful performance, it did not help anxious students to alleviate their MPA (Ryan, 2004). It is noteworthy that Ryan (2004) and Topoglu (2014) have low sample size. Therefore, it supports the idea that MTC' daily musical instrument (piano) practice hours and MPA should be investigated in more detail.

In the present study the level of mindfulness of MTC differed according to their DPPT. MTC who practice piano less than 1 hour a day or practice piano 1-2 hours a day have lower mindfulness levels than those who practice piano more than 2 hours a day. In other words, as the DPPT increased, the levels of mindfulness of the MTC increased. The positive correlation of mindfulness and DPPT shows that working hard on piano can be a reason for higher mindfulness levels. In this respect not only mindfulness practice but also regular piano practice can affect music performers' mindfulness levels. As far as I could uncover, there were no studies investigating specifically the relationship between mindfulness and DPPT. In addition, Kocaarslan (2016) in her research on MTC found a significant difference between students' daily musical instrument practicing time and their mindfulness levels. According to Kocaarslan's results, students who play their instrument less than 1 hour a day have lower mindfulness levels than students who play more than 1 hour (Kocaarslan, 2016). The result obtained by Kocaarslan is in parallel with this research and supports the positive relationship between mindfulness and daily musical instrument (piano) practicing time.

Recent literature emphasizes that empirical studies on trait mindfulness in the educational context are rare, despite an emerging common interest in contemplative pedagogical practices (Roeser \& Peck, 2009; Shapiro et al., 2015; Waters, Barsky, Ridd, \& Allen 2015; Grund, 2018), more empirical research on trait mindfulness in the educational context should be conducted. From the contradictory results obtained from other studies conducted with this research, the relationship between mindfulness and musical instrument (or piano) lesson achievement could be recommended to be examined in more depth. New studies should be conducted in order to eliminate the lack of studies on piano students' MPA and mindfulness levels. Within the framework of the results obtained in this study, it is recommended to apply the techniques using mindfulness to cope with stress in order to reduce the MPA of the MTC. In addition, it is recommended that new research should be conducted to examine the student's MPA and mindfulness in terms of different variables. The results of this research were limited to 524 MTC. In order to generalize the results, new research could be carried out on the relationships of these variables on different age groups, amateur performers or professional musicians with a larger sample.

\section{References}

Alpar, R. (2016). Spor, saglik ve egitim bilimlerinden orneklerle uygulamal istatistik ve gecerlik-guvenirlik [Applied statistics and validity-reliability with examples from sports, health and education sciences]. Ankara: Detay Yayıncilik.

Alyaprak, İ. (2006). Universite sinavina hazırlanan ogrencilerde sinav kaygısını etkileyen faktorlerin incelenmesi (Master's thesis, Ege University, İzmir, Turkey).

Baer, R. A., Smith, G. T., Hopkins, J., Krietemeyer, J., \& Toney, L. (2006). Using self-report assessment methods to explore facets of mindfulness. Assessment, 13(1), 27- 45. https://doi.org/10.1177/1073191105283504

Bishop, S. R., Lau, M., Shapiro, S., Carlson, L., Anderson, N. D., Carmody, J., ... Devins, G. (2004). Mindfulness: A proposed operational definition. Clinical Psychology: Science and Practice, 11(3), 230-241. https://doi.org/10.1093/clipsy.bph077

Bowlin, S. L., \& Baer, R. A. (2012). Relationships between mindfulness, self-control, and psychological functioning. Personality and Individual Differences, 52(3), 411-415. 
https://doi.org/10.1016/j.paid.2011.10.050

Brausch, B. D. (2011). The role of mindfulness in academic stress, self efficacy, and achievement in college students (Master's thesis, Illinois University, Charleston. USA). Retrieved from https://thekeep.eiu.edu/theses/147

Brown, K. W., \& Ryan, R. M. (2003). The benefits of being present: Mindfulness and its role in psychological well-being. Journal of Personality and Social Psychology, 84, 822-848. https://doi.org/10.1037/0022-3514.84.4.822

Brown, K. W., Ryan, R. M., \& Creswell, J. D. (2007). Mindfulness: Theoretical foundations and evidence for its salutary effects. Psychological Inquir, 18, 211-237. https://doi.org/10.1080/10478400701598298

Chang, J. C., Midlarsky, E., \& Lin, P. (2003). Effects of Meditation on music performance anxiety. Medical Problems of Performing Artists, 18(3), 126-130. https://doi.org/10.21091/mppa.2003.3022

Cruz, O. L., \& Carvajal, R. R. (2014). Mindfulness and music: A promising subject of an unmapped field. International Journal of Behavioral Research and Psychology, 2(3), 27-35. https://doi.org/10.19070/2332-3000-140006

Davidson, R. J. (1998). Affective style and affective disorders: perspectives from affective neuroscience. Cognition and Emotion, 12(3), 307-330. https://doi.org/10.1080/026999398379628

Duman, G. K. (2008). Illkogretim 8. sinif ogrencilerinin durumluk surekli kaygi duzeyleri ile sinav kaygisi duzeyleri ve ana - baba tutumlari arasindaki iliskinin incelenmesi (Master's thesis, Dokuz Eylul University, İzmir. Turkey). Retrieved from https://tez.yok.gov.tr/UlusalTezMerkezi/tezSorguSonucYeni.jsp

Gabrielsson, A. (1999). The performance of music. The psychology of music (Edited by Diana Deutsch, 2nd ed.). New York: Academic Press. https://doi.org/10.1016/B978-012213564-4/50015-9

Grodd, V. A. F. (2012). Mindfulness and the self-regulation of music performance anxiety (Doctoral dissertation). Retrieved from http://hdl.handle.net/2292/19993

Grodd, V. A. F. \& Cameron, L. (2013) Mindfulness and the self-regulation of music performance anxiety. International. Symposium on Performance Science. Published by the AEC

Grund, A., \& Senker, K., (2018). Motivational foundations of self-control and mindfulness and their role in $\begin{array}{llllll}\text { study-leisure conflicts. Learning and Individual Differences, } 68, & \text { 72-84. }\end{array}$ https://doi.org/10.1016/j.lindif.2018.10.007

Gun, E., \& Yıldız, G., (2014). Muzik ogretmeni adaylarina yonelik piyano performansi oz yeterlik olceginin gelistirilmesi. Turkish Studies International Periodical for the Languages, 9(5), 1053-1065. https://doi.org/10.7827/TurkishStudies.6896

Guven, E. (2016). Anxiety and piano exams: Turkish prospective music teachers' experiences. Music Education Research, 18(3), 305-316. https://doi.org/10.1080/14613808.2015.1122748

Hall, P. D. (1999). The effect of meditation on the academic performance of African American college students. Journal of Black Studies, 9(3), 408-415. https://doi.org/10.1177/002193479902900305

Howell, A.J. \& Buro, K. (2011). Relations among mindfulness, achievement-related self-regulation, and achievement emotions. Journal of Happiness Studies: An Interdisciplinary Forum on Subjective Well-Being, 12(6), 1007-1022. https://doi.org/10.1007/s10902-010-9241-7

Jelen, B. (2017). Muzik ogretmeni adaylarının muzik performans kaygısı ve piyano performans oz yeterlik duzeylerinin incelenmesi [The correlation between music performance anxieties and piano performance self efficacy levels of pre-service music teachers]. Idill, 39(6), 3389-3414. https://doi.org/10.7816/idil-06-39-22

Jha, A. P., Krompinger, J., \& Baime, M. J. (2007). Mindfulness training modifies subsystems of attention. Cognitive Affective and Behavioral Neuroscience, 7, 109-119. https://doi.org/10.3758/CABN.7.2.109

Kabat-Zinn, J. (1990). Full catastrophe living: How to cope with stress, pain and illness using mindfulness meditation. New York: Bantam Dell.

Kabat-Zinn, J. (1994). Wherever you go, there you are: mindfulness meditation in everyday life. New York: Hyperion.

Kabat-Zinn, J. (2003). Mindfulness-based interventions in context: past, present, and future. Clinical Psychology: Science and Practice, 10(2), 144-156. https://doi.org/10.1093/clipsy.bpg016 
Kabat-Zinn, J. (2012). Mindfulness for beginners. Boulder, CO: Sounds True.

Kafadar, A. (2009). Piyanistler Orneginde Muzisyenlere Ozgu Performans Anksiyetesi (Master's thesis, Dokuz Eylul University, İzmir, Turkey).

Karasar, N. (2004). Bilimsel arastırma yontemi (On Ucuncu Baskı). Ankara: Nobel Yayın Dagıtım.

Keng, S. L., Smoski, M. J., \& Robins, C. J. (2011). Effect of mindfulness on psychological health: a review of empirical studies. Clinical Psychology Review, 31, 1041-1056. https://doi.org/10.1016/j.cpr.2011.04.006

Kenny, T. D., Davis, P., \& Oates, J. (2004). Music performance anxiety and occupational stress among opera chorus anxiety and their relationship with state and trait anxiety and perfectionism. Journal of Anxiety Disorders, 18(6), 757-777. https://doi.org/10.1016/j.janxdis.2003.09.004

Kınay, F. (2013). Beş boyutlu bilinçli farkındalık ölçeği’ni türkçe'ye uyarlama, geçerlik ve güvenirlik çalışması (Master's thesis, İstanbul Bilim University, İstanbul, Turkey).

Kocaarslan, B. (2016). Profesyonel Müzik Eğitiminde Bilinçli Farkindalı, Öğrenme Stratejileri ve Öğrenme $\begin{array}{lllll}\text { Stilleri (Doctoral dissertation). } & \text { Retrieved }\end{array}$ https://tez.yok.gov.tr/UlusalTezMerkezi/tezSorguSonucYeni.jsp

Kucuk, D. P. (2010). Muzik ogretmeni adaylarının sınav kaygısı, benlik saygısı ve calgı basarıları arasındaki iliskinin incelenmesi. Ahi Evran University Egitim Fakultesi Dergisi, 11(3), 37-50. Retrieved from https://dergipark.org.tr/tr/pub/kefad/issue/59502/855332

Lang, A. (2000). The schlaffhorst-Anderson method for the prevention and treatment of stage fright. ISSTIP Journal. Retrieved from https://citeseerx.ist.psu.edu/viewdoc/download?doi=10.1.1.622.7773\&rep=rep1\& type $=$ pdf

Leland, M. (2015). Mindfulness and student success. Journal of Adult Education, 44(1), 19-24. Retrieved from https://files.eric.ed.gov/fulltext/EJ1072925.pdf

Lin, P., Chang, J., Zemon, V., \& Midlarsky, E. (2008). Silent illumination: A study on Chan (Zen) meditation, anxiety and musical performance quality. Psychology of Music, 36(2), 139-155. https://doi.org/10.1177/0305735607080840

Metallidou, P., \& Vlachou, A. (2007). Motivational beliefs, cognitive engagement, and achievement in language and mathematics in elementary school children. International Journal of Psychology, 42, 2-15. https://doi.org/10.1080/00207590500411179

Morris, L. W., Kellaway, D. S., \& Smith, D. H. (1978). Mathematics anxiety rating scale: predicting anxiety experiences and academic performance in two groups of students. Journal of Educational Psychology, 70(4), 589-594. https://doi.org/10.1037/0022-0663.70.4.589

Nacakcı, Z., \& Dalkıran, E. (2011). Muzik egitimi anabilim dalı ogrencilerinin bireysel calgı sınavına yonelik kaygıları. Mehmet Akif Ersoy University Sosyal Bilimler Enstitusu Dergisi, 5, 46-56. Retrieved from http://oaji.net/articles/2014/1037-1405505878.pdf

Oyan, S. (2006). Mindfulness Meditation: Creative Musical Performance Through Awareness (Doctoral dissertation). Retrieved from https://digitalcommons.lsu.edu/gradschool_dissertations/3922

Ozyesil, Z., Arslan, C., Kesici, S., \& Deniz, M. E. (2011). Bilincli farkındalık olcegi'ni Turkceye uyarlama calısması. Egitim ve Bilim, 36, 160. Retrieved from http://egitimvebilim.ted.org.tr/index.php/EB/article/view/697/271

Pirgon, Y. (2017). Guzel sanatlar fakultesi muzik bolumu ogrencilerinin sosyal fobi duzeyleri ile basarıları arasındaki iliskinin incelenmesi. Uluslar Arası Hakemli Muzik Arastırmaları Dergisi, 10(4), 1-19. https://doi.org/10.17370/uhmad.2007.2.1

Rodgers, L. (2014). A calmer happier kid. Scholastic Parent and Child, 21(6), 60-63.

Rodzaj, J. K. (2020). Music performance anxiety and pre-performance emotions in the light of psychology of emotion and emotion regulation. Psychology of Music. https://doi.org/10.1177/0305735620961154

Roeser, R. W., \& Peck, S. C. (2009). An education in awareness: self, motivation, and self regulated learning in $\begin{array}{llll}\text { contemplative } & \text { Perspective. } & \text { Educational }\end{array}$ https://doi.org/10.1080/00461520902832376

Ruiz, E. H., Dvorak, A. L., \& Weingarten, K. (2020). Music stimuli in mindfulness meditation: Comparison of musician and non-musician responses. Psychology of Music. https://doi.org/10.1177/0305735620901338 
Ryan, C. (2004). Gender differences in children's experience of musical performance anxiety. Psychology of Music, 32(1), 98-103. https://doi.org/10.1177/0305735604039284

Sahin, N., H., \& Yeniceri, Z. (2015). "Farkındalık" uzerine uc arac: Psikolojik farkındalık, butunleyici kendilik farkındalıg1 ve Toronto bilgece farkındalık olcekleri. Turk Psikoloji Dergisi, 30(76), 48-64.

Salmon, P. G., \& Meyer, R., G. (1992). Notes from the green room: Coping with stress and anxiety in musical performance. San Francisco, CA: Jossey-Bass.

Saucier, E. A. (2011). The Effect of Trait Mindfulness on Acute Stress is Gender and Affect Dependent (Master's thesis, Brandeis University, Waltham, Massachusetts). Retrieved from http://hdl.handle.net/10192/14

Schwind, J. K., McCay, E., Beanlands, H., Schindel, M. L., Martin, J., \& Binder, M. (2017). Mindfulness practice as a teaching-learning strategy in higher education: A qualitative exploratory pilot study. Nurse Education Today, 50, 92-96. https://doi.org/10.1016/j.nedt.2016.12.017

Shapiro, S. L., Brown, K. W., Thoresen, C., \& Plante, T. G. (2011). The moderation of mindfulness-based stress reduction effects by trait mindfulness: Results from a randomized controlled trial. Journal of Clinical Psychology, 6, 267-277. https://doi.org/10.1002/jclp.20761

Shapiro, S. L., Lyons, K. E., Miller, R. C., Butler, B., Vieten, C., \& Zelazo, P. D. (2015). Contemplation in the classroom: A new direction for improving childhood education. Educational Psychology Review, 27, 1-30. https://doi.org/10.1007/s10648-014-9265-3

Steinfeld, M., \& Brewer, J. (2015). The psychological benefits from reconceptualizing music-making as mindfulness practice. Medical Problems of Performing Artist, 30, 84-89. https://doi.org/10.21091/mppa.2015.2014

Steptoe, A., \& Fidler, H. (1987). Stage fright in orchestral musicians: A Study of cognitive and behavioral strategies in performance anxiety. British Journal of Psychology, 78, 241-249. https://doi.org/10.1111/j.2044-8295.1987.tb02243.x

Tokarz, A., \& Kaleńska, J. (2005). Skala samopoczucia muzyka przed występem-A. Steptoe I H. Fidler-Wstępne Opracowanie Wersji Polskiej [Self-statement scale for musicians-a. steptoe and H. Fidler-The polish adaptation]. Psychologia Rozwojowa, 10, 125-135.

Tokinan, B., O., (2013). Kenny Muzik Performans Kaygısı Envanterini Turkce'ye Uyarlama Calısması. Ahi Evran University Kirsehir Egitim Fakultesi Dergisi (KEFAD), 14(1), 53-65. Retrieved from $\mathrm{http}: / /$ dergipark.gov.tr/download/article-file/15859

Ulev, E. (2014). Universite ogrencilerinde bilincli farkindallk duzeyi ile stresle basa cikma tarzinin depresyon, kaygi ve stres belirtileriyle iliskisi (Unpublished master's thesis). Hacettepe University. Ankara. Turkey.

Valentine, E. R. (2002). The fear of performance. Musical performance: A guide to understanding. Cambridge: Cambridge University Press. https://doi.org/10.1017/CBO9780511811739.013

Waters, L., Barsky, A., Ridd, A., \& Allen, K. (2015). Contemplative education: A systematic, evidence-based review of the effect of meditation interventions idxn schools. Educational Psychology Review, 27, 103-134. https://doi.org/10.1007/s10648-014-9258-2

Weinstein, N., Brown, K. W., \& Ryan, R. M. (2009). A multi-method examination of the effects of mindfulness on stress attribution, coping, and emotional well-being. Journal of Research in Personality, 43(3), 374-385. https://doi.org/10.1016/j.jrp.2008.12.008

Wolters, C. A., \& Pintrich, P. R. (1998). Contexual differences in student motivation and selfregulated learning in mathematics, english, and social studies classrooms. Instructional Science, 26, 27-47. Retrieved from https://ink.springer.com/content/pdf/10.1023\%2FA\%3A1003035929216.pdf

Yıldırım, S., (2011). Self-efficacy, intrinsic motivation, anxiety and mathematics achievement: findings from Turkey, Japan and Finland. Necatibey Faculty of Education Electronic Journal of Science and Mathematics Education, 5(1), 277-291. Retrieved from http://dergipark.gov.tr/download/article-file/39823

Yokus, T., Yokus, H., \& Kalaycıglu, S. G. (2013). Muzik ogretmeni aday adaylarının surekli-durumluk kaygı duzeyleri ve muzik ozel yetenek sınavı basarıları arasındaki iliskinin incelenmesi. e-Journal of New World Sciences Academy NWSA-Fine Arts, 8(1), 153-163. Retrieved from http://dergipark.gov.tr/download/article-file/186516

Yoshie, M., Kudo, K., \& Ohtsuki, T. (2008). Effects of psychological stress on state anxiety, electromyographic 
activity, and arpeggio performance in pianists. Medical Problems of Performing Artists, 23(3), 120. https://doi.org/10.21091/mppa.2008.3024

\section{Note}

Note 1. One part of this study was presented at Turkic Session of 33rdWorld Conference of International Society for Music Education July 15-20, 2018 in Baku Azerbaijan.

\section{Copyrights}

Copyright for this article is retained by the author(s), with first publication rights granted to the journal.

This is an open-access article distributed under the terms and conditions of the Creative Commons Attribution license (http://creativecommons.org/licenses/by/4.0/). 